\title{
41919
}

\section{In/Visibilities and Pseudo/Visibilities: the black woman's portrait in the Bemposta chapel in Lisbon (1791-1792)}

\author{
Giuseppina Raggi
}

\begin{abstract}
:
Giuseppe Trono's painting in the Bemposta chapel, produced in 1791-1792, is the most representative artwork related to the social policies implemented by the Queen Mary I. This article focuses on the historical and artistic analyses to frame the political and religious context, and to clarify its misunderstood iconography. The cult of the Sacred Heart, instituted in 1779 by Pope Pius $\mathrm{VI}$, is crucial to reframe the meaning of the painting. The new approach offers an original interpretation of the black woman who is represented in it. Her identity and biography are brought to the light. Her subjectivity is compared to the more known biographies of the enslaved black dwarfs, who lived at the Portuguese royal court, mainly the female dwarf Rosa of the Sacred Heart, portraited in Mascarada Nupcial by José Conrado Roza (1788). Her in/visibility is compared, also, to the 'silence' about the black presence in the painting The earthquake of 1755 by João Glama ( $2^{\text {nd }}$ half of $18^{\text {th }}$ century).
\end{abstract}

Keywords: Giuseppe Trono; Bemposta chapel; enslaved and free African women; Queen Mary I; Black subjectivities in $18^{\text {th }}$ century Lisbon.

\section{Resumo:}

A pintura de Giuseppe Trono na capela da Bemposta, realizada in 1791-1792, é uma das obras mais representativas das políticas sociais implementadas pela rainha D. Maria I. Este artigo centra-se na análise histórico-artística da pintura para enquadrar o contexto político e religioso da época e esclarecer o significado da iconografia, que foi equivocado pela exígua historiografia existente sobre a obra. O culto do Sagrado Coração, instituído em 1779 pelo papa Pio VI, é crucial para decodificar o significado da pintura. A nova abordagem apresenta uma original 
interpretação da mulher negra representada na tela. A sua identidade e a sua biografia são trazidas à luz. A sua subjetividade é comparada com as biografias mais conhecidas do grupo de anões escravizados que viviam na corte de Lisboa; principalmente com a biografia de Rosa do Sagrado Coração de Jesus, retratada na Mascarada nupcial de José Conrado Roza (1788). A sua in/visibilidade é comparada, também, com o 'silêncio' sobre a presença negra na pintura $O$ terramoto de Lisboa de 1755 de João Glama, realizada na segunda metade do século XVIII.

Palavras-chave: Giuseppe Trono; Capela da Bemposta; Mulheres africanas escravizadas e libertas; a rainha D. Maria I; subjetividades negras na Lisboa setecentistas.

\section{The Bemposta chapel in Lisbon (1791-1792)}

In the royal palace of Bemposta, the chapel is a sumptuous building, which interior and façade were integrally restructured and redecorated in the second half of the $18^{\text {th }}$ century (Academia Militar, 2005).

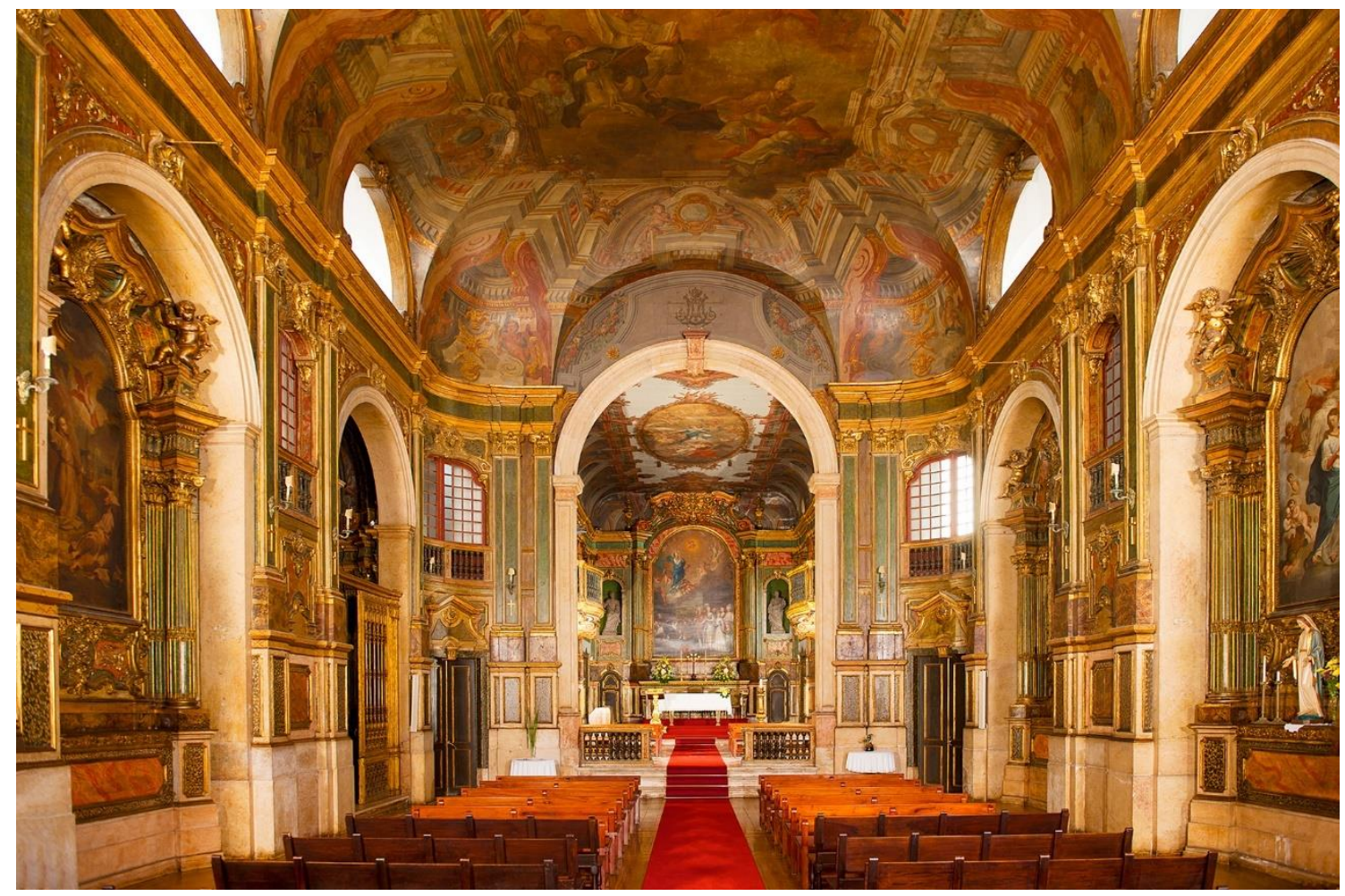

Figure 1: Chapel of the $18^{\text {th }}$ century royal palace of Bemposta, now Academia Militar (Raggi \& Degortes, 2018, fig. IV).

The altarpiece is a painting by Giuseppe Trono (Turin 1739 - Lisbon 1810), the Italian royal portraitist who lived and worked in Lisbon from 1785 to 1810 . The painting is one of the most important artworks within the Portuguese arts of the $18^{\text {th }}$ century last quarter, 
but, until recently, it was underestimated and misunderstood (Raggi \& Degortes 2018). It was underestimated because of the reductive critical appreciation by the art historian José Augusto França, who considered Giuseppe Trono as a painter without talent and the painting "as a curious mix of styles: very conventional in the sacred figures; more bright in the common people; and even without avoiding to copy and imitate the portraits, painted two years before by the Irish painter Thomas Hickey, in the royal family's figures" (França, 1967: 77).

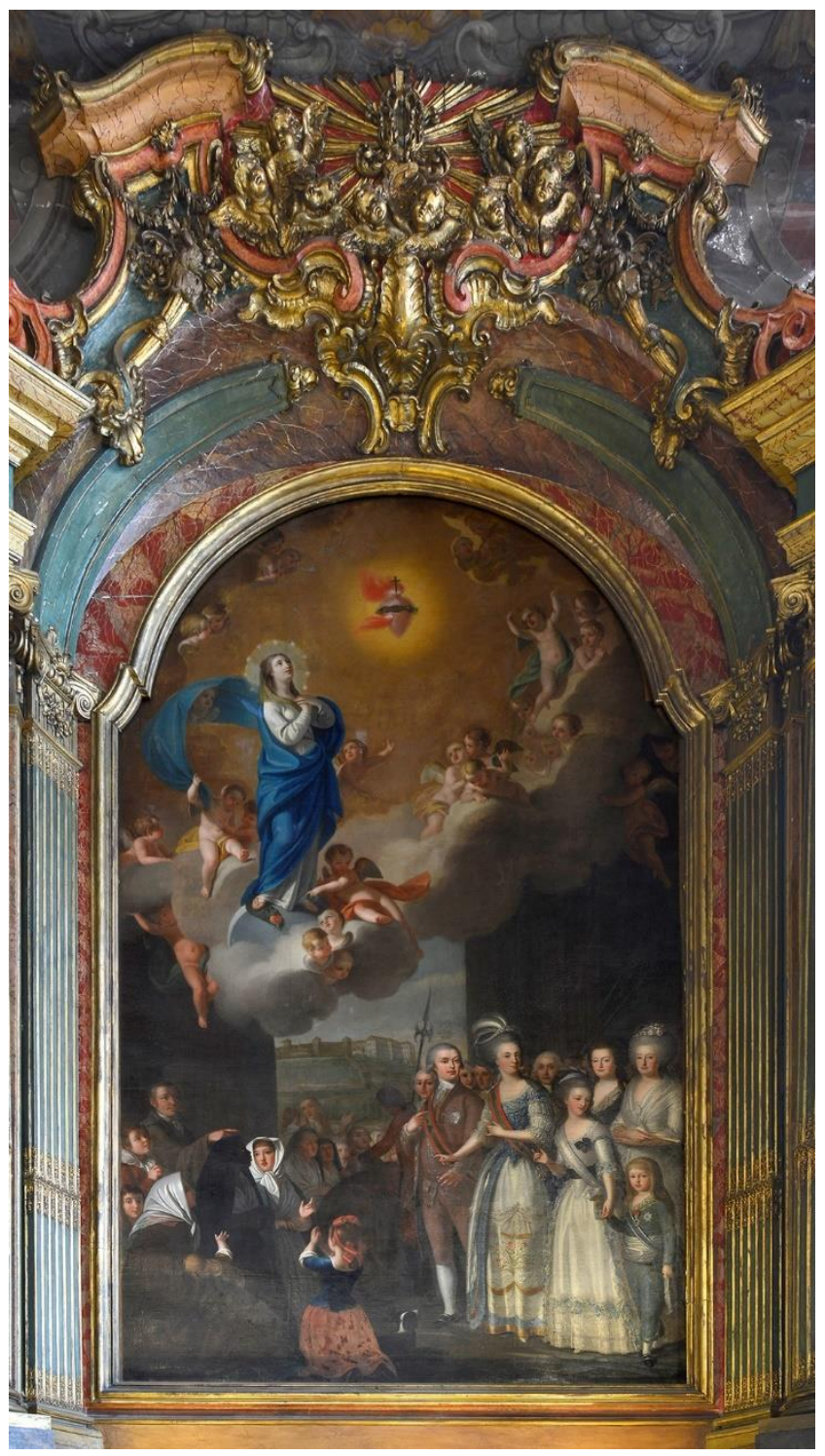

Figure 2: The altarpiece by Giuseppe Trono, 1791-1792 (Raggi \& Degortes, 2018, fig. VI).

Indubitably, the painting's iconography is very unusual. It is not based on recognizable patterns and it shows, on the right, Queen Mary I and the royal family; on the left, a group of people in which women and children prevail; above, Our Lady of Immaculate Conception who gazes at the Sacred Heart of Jesus. In the past, this altarpiece was 
referred with different titles, mostly with a periphrastic title, such as "a painting with the royal family and Our Lady of Immaculate Conception" (Borges, 1986: 154). The concepts of the Immaculate Conception and the presence of royal family were stressed. Nonetheless, in the rare descriptions dedicated to this painting, who most attracted the attention was the black woman, painted in the center of the group on the left.

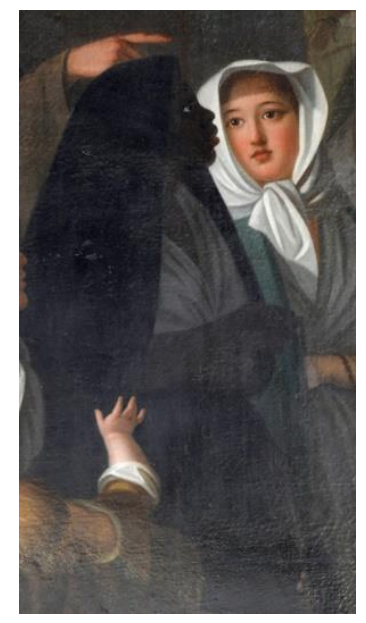

Figure 3: The black woman in the painting of the Bemposta chapel, 1791-1792. Detail.

\section{In/Visibilities}

In these descriptions, the black woman's presence in the group of common people was referred to reinforce the idea of the Portuguese multi-ethnic and peaceful society (Moita, 2005/1955). This approach characterized the luso-tropicalist ideas about the Portuguese colonial domination in the early-modern and modern world. Thus, this kind of visibility perpetuated the false image of the Portuguese colonial domination as colonialismo brando (Bethencourt, 2015; Rossa \& Ribeiro, 2015). The black woman remained 'invisible' without identity, name and history, as well as everyone else in the left group. For that and other reasons, the painting as a whole continued misunderstood.

Giuseppe Trono painted this artwork soon after the French revolution. For the profound changes that characterized that historical period, the painting's style was overstepped by the new artistic visions developed between the $18^{\text {th }}$ and $19^{\text {th }}$ centuries; and its meaning was overwhelmed by the historical events. Already in the early years of the $19^{\text {th }}$ century, its meaning was completely distorted. While the Portuguese regent and the royal court were preparing to leave the Kingdom and escape to Brazil, the French artist Zacharie-Félix Doumet (1761-1818) drew the watercolors Costumes portugueses. He stayed in Portugal for ten years, until 1806, earning his living as a draughtsman for the military engineering corps, while at the same time continuing his artistic activity. His artworks are known as urban scenes with popular figures that visualize the true Lisbon 
city life; but, at least, in one case, the image is not so realistic as it appears. The watercolor Attitudes des Portugaises à l'eglise invented a false image of Portuguese society and its religious traditions.

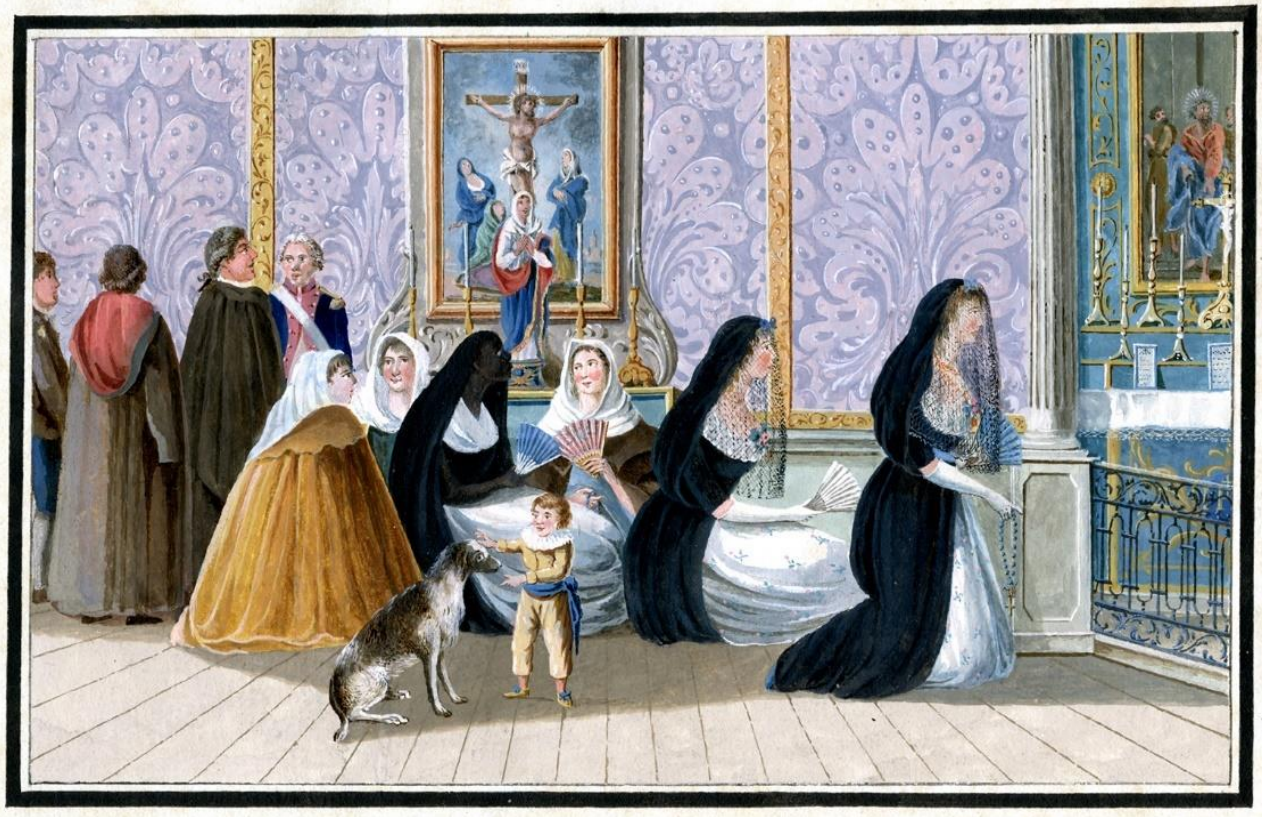

A'TTITUDE DES PORTUGAISES A L'ÉGLISE.

Figure 4: Zacharie Felix Doumet, Attitudes des Portugaises à l'eglise, 1806. Lisbon, Portugal: Museu da Cidade, MC.PIN.0299. 


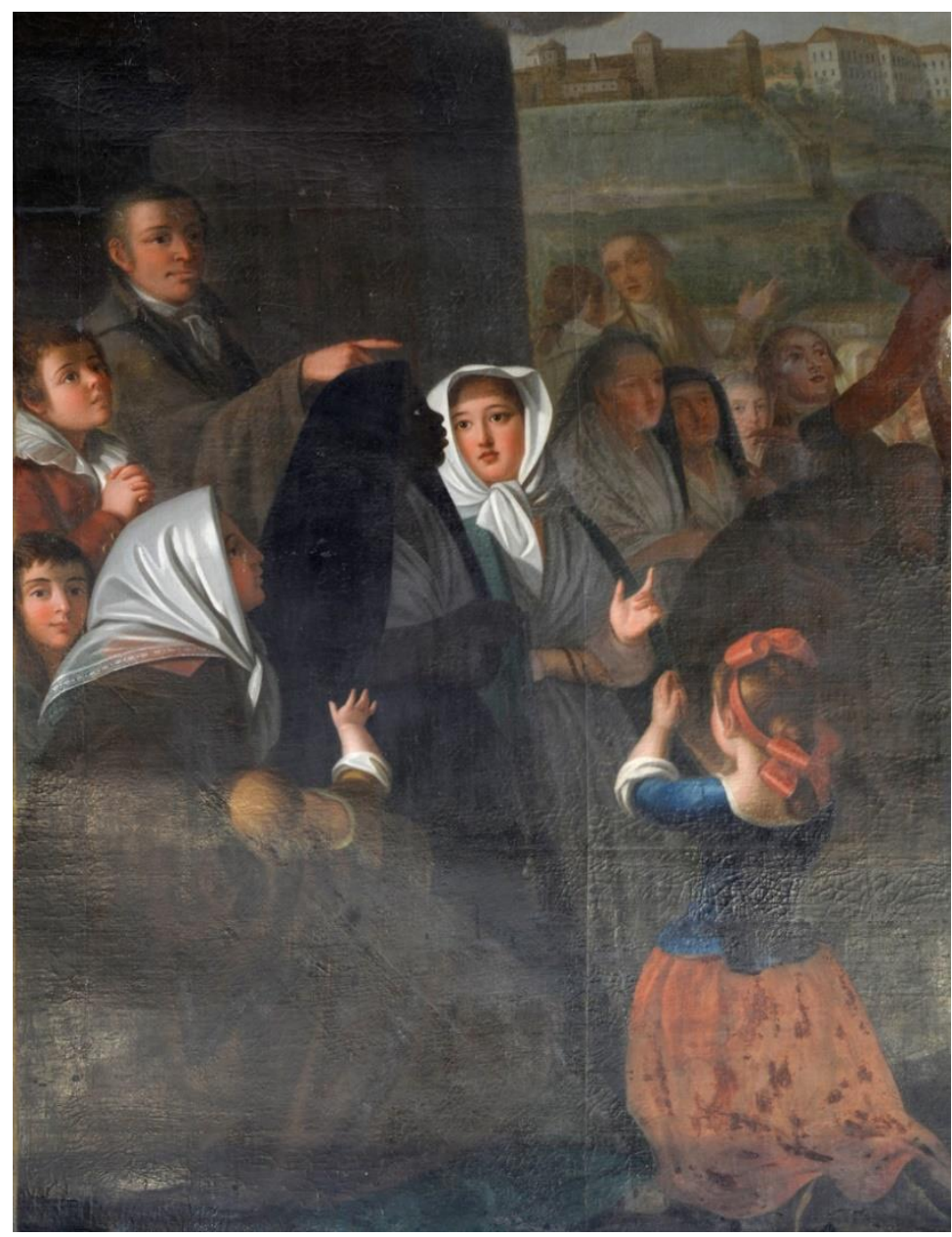

Figure 5: The altarpiece by Giuseppe Trono, 1791-1792. Detail (Raggi \& Degortes, 2018, fig. XXV).

Undoubtedly, Zacharias-Félix Doumet visited the Bemposta chapel and he was impressed by this Trono's painting, specially by the black woman's figure. Doumet did not recognize the original iconography, but only the singularity of the painting and, in his watercolor, he reconstructed another 'reality'. He combined the two groups, painted by Trono on the right and on the left of the canvas, into only one. In the center, the black woman maintains the same gaze, but she holds in her hands a folding fan, no more a rosary as in the original painting. The two white women at her side (the woman with the newborn in the arms, and the woman who looks at her) become three and they sit around the black lady, and their attitudes seem more attracted to chatting with each other than praying. The female child who prays kneeling near the little dog is reconverted in a little boy who plays with a big dog. The standing men are dressed in different clothes that correspond to their different social roles, but they seem more interested in conversing than in praying. Only the two women who pray in front of the altar, the first with fan and rosary, are represented in more hieratic and devoted attitudes. Their clothes in flowered tissue, the veil, and the jewels that can be glimpsed below connect these women with 
the female members of the royal family in Trono's altarpiece. Zacharie-Félix Doumet totally ignored the images of Our Lady of Immaculate Conception and the Sacred Heart of Jesus painted in the altarpiece, and transformed the painting into a secular scene that takes place in a sacred space. The high number of portraits attracted his artistic imagination, especially the black woman who he puts in the center of his watercolor. He aimed to represent the Portuguese Customs and the Bemposta's painting gave him a perfect model to create a virtual Portuguese reality. Without understanding the original meaning of the altarpiece, he sweetened the Portuguese social reality based on centuries of slaver domination.

\section{Pseudo/Visibilities}

In 2018, the black woman became the image of one of the characters narrated by the historical romance $D$. Maria I. Uma rainha atormentada por um segredo que a levou à loucura (Stilwell, 2018: 457-458).

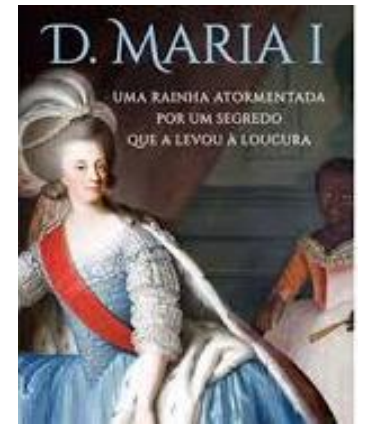

Figure 6: Book cover with the portraits of Queen Mary I and the enslaved black dwarf Rosa

The alleged historicity of this literary work moves it from the creative fiction's field to that of historical manipulation in function of an imaginary story. The authoress carried out a shift of identity, projecting on the black woman of Trono's painting the most famous enslaved female who the current Portuguese readers well know. She is Rosa, the black dwarf described by the English traveller William Beckford in 1787 (Boyd, 2009; Franco, Oliveira \& Vale, 2018: 321). She had landed at Lisbon in 1781 and died in 1790, living at the Portuguese court for delighting the Queen.

Despite the black figure in the Bemposta chapel has not any of the physical characteristics immortalized by José Conrado Roza in the famous work Mascarada Nupcial (1788), the novel describes the black woman as the embellished portrait of Rosa. So, the 'historical' romance gives a pseudo/visibility to Rosa, contributing, at the same time, to make invisible two subjectivities: that of Rosa, whom story is distorted; and that of the black woman, whom history is denied. 


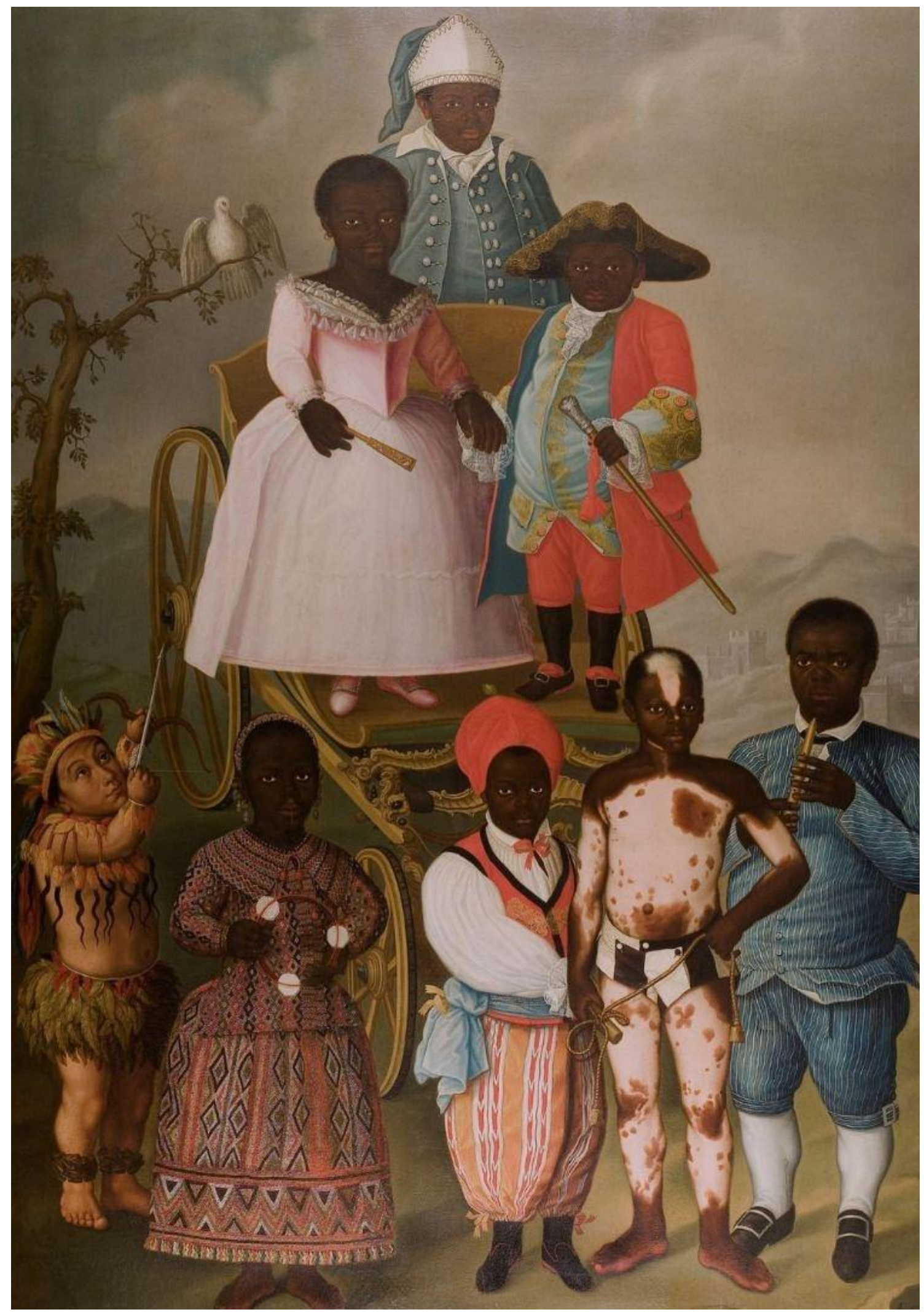

Figure 7: José Conrado Roza, Mascarada Nupcial, 1788. La Rochelle, Musées d'Art et d'Histoire de la Rochelle - Musée du Noveau Monde, inv. MNM.1983.7.1. 


\section{Staging history: the power of the Sacred Heart of Jesus}

The kingdom of Mary I was characterized by the liturgical institution of the Sacred Heart of Jesus cult. Starting from the visions of the nun Margaret-Mary Alacoque at the end of the $17^{\text {th }}$ century, the devotion for the Sacred Heart of Jesus had spread in Europe, promoted by Jesuits and Franciscans. The Vatican, however, established the specific liturgy and fest for this cult only in the second half of the 18th century, when it acquired an important political meaning (Menozzi, 2001). Pope Pius VI promoted this change to contrast the Enlightenment philosophy, intended as disintegrating force against the catholic religion and the monarchical institution.

So, from a private devotional dimension, the cult of the Sacred Heart of Jesus became the privileged instrument for strengthening the union between politics and religion, between monarchy and Vatican. Immediately after the Queen's acclamation to the throne, Pius VI accepted her request to grant the liturgical institution of the Sacred Heart feast in the Portuguese kingdom and in all its overseas colonial territories. In 1778, the Vatican approved it; and in June of 1779 the religious feast was celebrated, for the first time in Portugal, right in the royal chapel of the Bemposta. In the same year, in October, the first stone of the first church in the world dedicated to the Sacred Heart of Jesus was placed. This church is, currently, best known as the Basilica of Estrela. During the $1780 \mathrm{~s}$, the basilica was built and, at the same time, the interior of Bemposta chapel was also restructured and redecorated.

Although the construction of the basilica was just beginning, the Portuguese Queen chose the famous artist Pompeo Batoni (1708-1787) to paint, in Rome, the large canvas for the main altar. In 1765, he had provided the first iconography of the Sacred Heart, depicting the image of Jesus Christ who holds and shows in his hand his blazing heart, pierced and full of redeeming love. After heated theological debates, Pope Pius VI had accepted the isolated representation of the Sacred Heart as a living and pulsating organ, such as the nun Margaret-Mary Alacoque had seen it in vision. For the important Portuguese commission, Pompeo Batoni chose this iconography of the Sacred Heart, creating a complex allegorical representation of the new cult. 


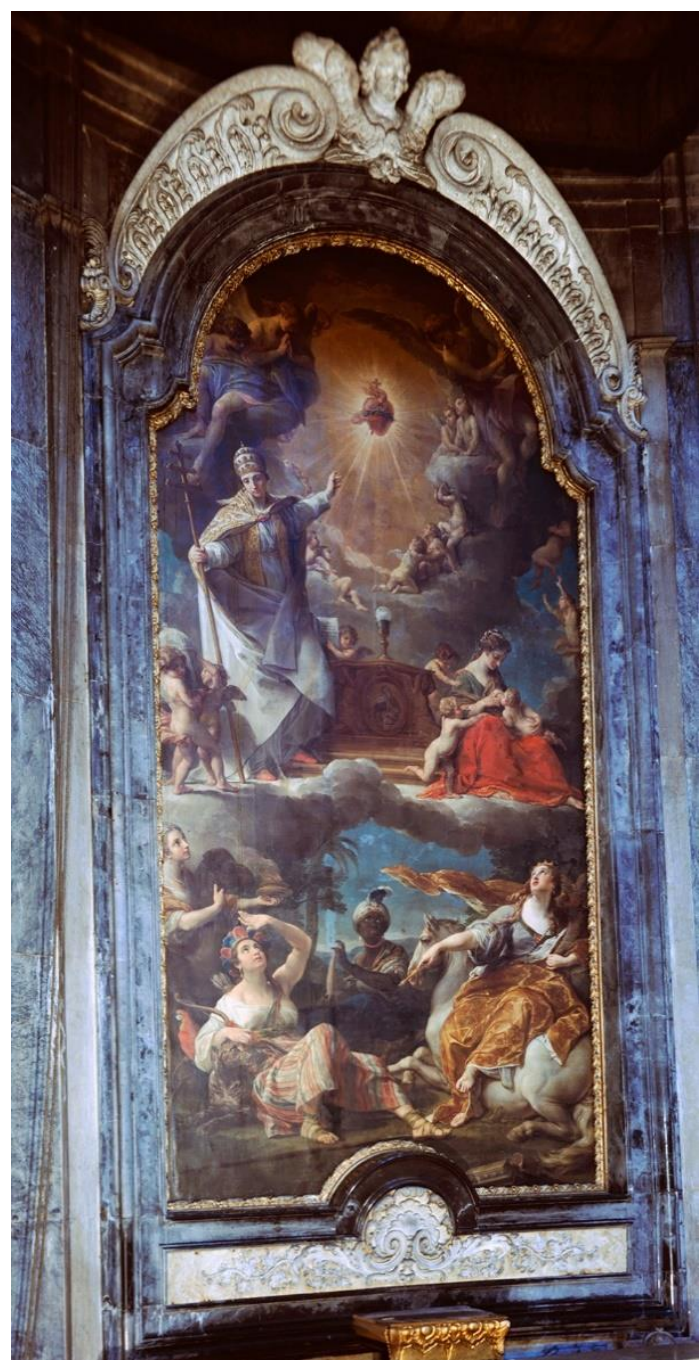

Figure 8: The altarpiece by Pompeo Batoni in the Basilica of Estrela, 1780-1781 (Raggi \& Degortes, 2018, fig. V).

The painting represents The consecration of the world to the Sacred Heart of Jesus, painted in 1780-1781. Before sending the canvas to Lisbon, Pope Pio VI went personally to the artist's studio to see the painting, and approved the new iconography. In the upper, heavenly dimension, the Sacred Heart radiates its strength of love, which is present in the Eucharist, represented just under the Sacred Heart, in the intermediate dimension between heaven and earth. On the left, the pope shows the Sacred Heart to the four continents, and he represents allegorically the Church and its role for diffusing the cult. On the right, the allegory of Charity indicates how to follow the love spread by the Sacred Heart of Jesus.

On the floor, the allegory of Europe, painted on the right, rides a white horse and shows the symbols of royal power (the crown and the scepter) as clear reference to the power of the Queen Mary I. The figure of Europe dominates the other three continents (America, Africa and Asia) represented in front of her. The iconography conceived by Pompeo Batoni and approved by Pope Pius VI affirmed the worldwide dimension of the Sacred 
Heart cult and the political role of the Portuguese monarchy to spread it through its overseas colonial territories.

The large canvas arrived in Lisbon in 1782, but the basilica was consecrated only in 1789. The work of Pompeo Batoni remained for a long time accessible to the study of the royal court painters.

\section{The Sacred Heart and the politics of charity: the people of Lisbon city}

In 1784, Queen Maria I sought in Italy a good painter of portraits, and chose Giuseppe Trono from Turin. He arrived in Lisbon in march of 1785 and carried out a very intense pictorial activity, painting all the royal family members and the government ministers. The construction of the basilica of Estrela continued and also that of the Bemposta chapel. The basilica was consecrated in 1789 and the chapel in 1793. On this occasion the devotion of the Immaculate Conception, to which the chapel was originally dedicated, was associated with the new cult of the Sacred Heart.

Around 1791, Giuseppe Trono painted the altarpiece of the Bemposta chapel. He carefully studied the canvas by Pompeo Batoni and conceived his artwork in close connection with the artistic composition and the meaning of the basilica altarpiece.

On the right the royal family group is magnificently portraited. At that time, the prince Joseph had already died; so, his brother, the infant John, who would become future king John VI, interchanges gestures with his mother which symbolize the sharing of the power. Indeed, around 1792, the Queen's mental health began to falter. Near the Queen there is one of the most beautiful portraits of the Spanish princess Carlota Joaquina of Bourbon (future Queen of Portugal), who holds by the hand the little infant Peter Charles of Braganza and Bourbon, son of the infants Gabriel of Bourbon and Mariana Vitoria of Braganza, deceased in 1788.

Behind them, the princess-widow Francisca Benedicta of Braganza is represented integrally. She was a very powerful member of royal family, because she maintained the title of princess of Brazil despite the death of her husband-nephew in 1788, the prince Joseph. On her right side, it is visible just the face of the infant Mariana of Braganza, Queen's and Princess-widow's sister.

In front of the royal family there is another group of people, which identity is unknown. In the past, they were interpreted as 'people', as 'common persons', which names did not matter. Without doubt, it is more difficult (re)discovering their identities, but it is not impossible. The first step is to not settle for the generic description and asking «who could be this people? ». The painting itself offers some clues.

In the royal family's group, behind the Queen, there is the portrait of the police-chief Diogo de Pina Manique. In the early 1790s, Pina Manique had achieved a strong position 
of power within the Portuguese court and government, thanks to his role as director of the Real Casa Pia, an assistance institution founded by the Queen in 1780 (Tavares \& Pinto, 1990). In the painting's background, the representation of the Real Casa Pia first headquarters, located near the ancient castle of São Jorge, confirms the connection between the iconography and the social policies of Mary I. Diogo de Pina Manique, as chief of the new police institution, and director of the Real Casa Pia, led the implementation of these politics inspired by the religious principles of the Sacred Heart cult. The Real Casa Pia was both prison for men and women, and orphanage for the children. The police patrolled the streets of the city of Lisbon, having the power to lock up tramps, beggars, prostitutes, and abandoned children. The Real Casa Pia had sections for all different kinds of reclused people. Here, all of them received education or professional qualification.

\section{Children and women of Lisbon city: the black woman's life story}

Thus, it is possible to argue that the group painted on the left represents the people who lived in the Real Casa Pia. Among them, Giuseppe Trono privileged women and children. But, who were these women and children? How did they live in the Real Casa Pia? The children who lived in the institution were orphaned or abandoned on the streets of the city. Among them, there were also the sons of the women reclused. The children were literate and then they learned manufacturing jobs (Tavares \& Pinto, 1990; Beirão, 1944). Among the male, some were instructed in the artistic fields (painting, sculpture, engraving), and the most skilled went to Rome to study at the Academia Portuguesa de Belas Artes (Degortes, 2016).

The assistance to women focused on three categories: prostitutes (mulheres de vida escandalosa); single mothers; and poor girls without dowry for marry. These women lived in the section named "Saint Margaret of Cortona". Margaret was a $13^{\text {th }}$ century Italian woman who lived more uxorio with a man, had a child with him and was rejected by her family. She entered the convent and lived an extremely devoted life. Only in 1728, that is, more than four hundred years later, she was proclaimed saint by Pope Benedict XIII, as saint patron of the repented prostitutes (Canosa \& Colonnello, 2004). The purpose of this Real Casa Pia section, placed under the protection of Santa Margherita of Cortona, was not only to remove these women from the street, but to give them the opportunity to repent and redeem themselves.

In Giuseppe Trono's painting there are easily recognizable persons belonging to these categories. There are children with their mentor, probably a professor of art who indicates the royal family as the source of their education and assistance. The little girl who prays with the other women could have been orphaned or abandoned. The three women 
represent the three categories of women assisted by the Real Casa Pia: one of them holds in her arms a newborn and the black woman is dressed like a nun.

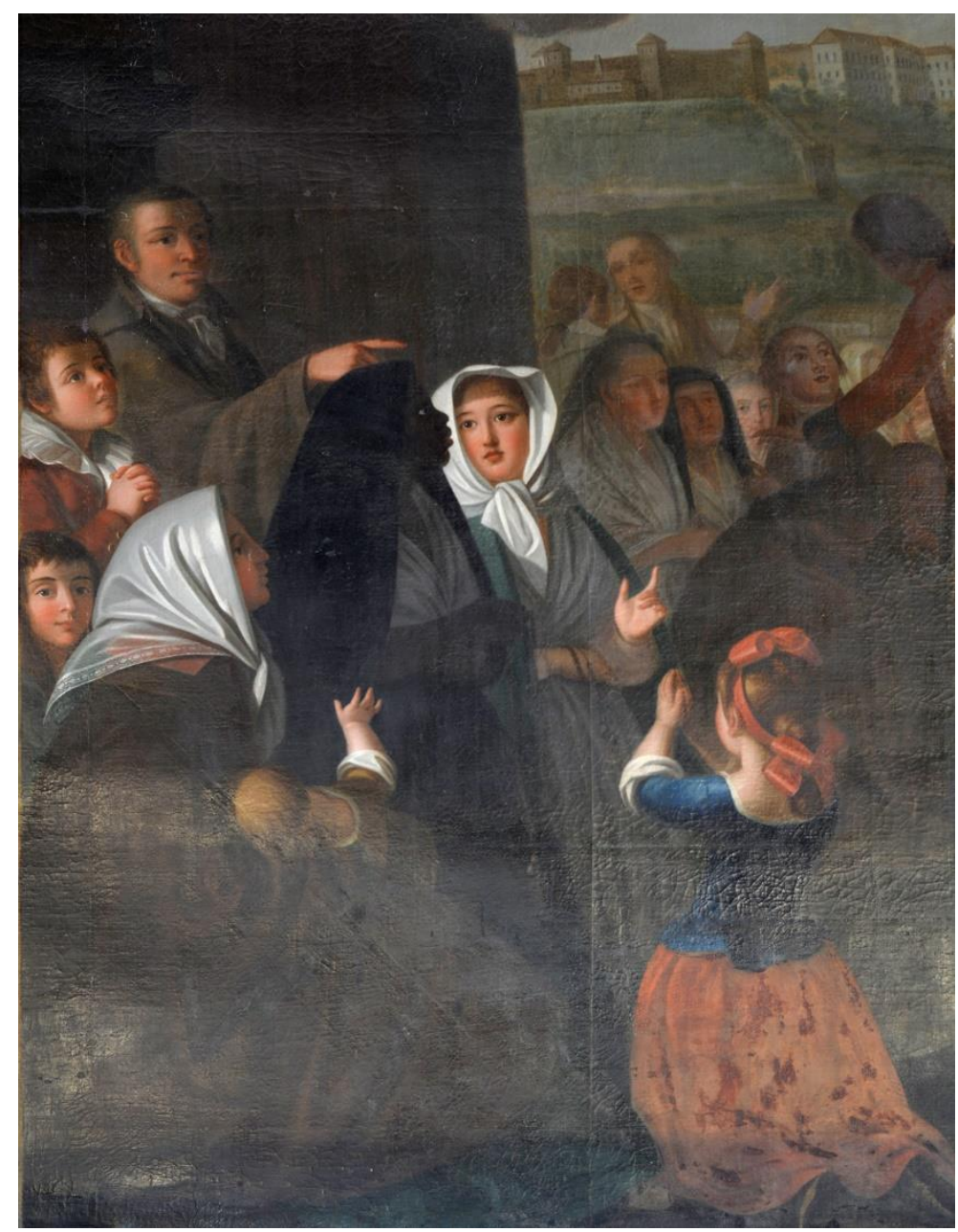

Figure 5: The altarpiece by Giuseppe Trono, 1791-1792 (detail) (Raggi \& Degortes, 2018, fig. XXV).

The black woman and the white woman, who looks at her, hold the rosary in their hands. Therefore, both dedicate themselves to prayer, and go through a common path of repentance and redemption. But the devoted attitude of the black woman, her clothing similar to that of the nuns, her dominant position within the group give her a special place. Why is the focus on her?

Some years after its foundation, corresponding to the main purpose of the Real Casa Pia, a new section was added under the invocation of Our Lady of Immaculate Conception. Here were welcomed the women who, during the redemption process experienced in the Santa Margherita da Cortona's section, embraced the desire to follow a religious lifestyle. In Our Lady of Immaculate Conception's section, these women lived a life similar to that of the nuns, they were led by spiritual directors and worked during the day kneading the bread (Silva, 1896: 31). The attitude and the cloths of the black 
woman testify her participation to the life of Our Lady of Immaculate Conception's section. She is represented as a model of redemption and faith to be imitated by other women. Her position in the painting is directly linked with the Queen Mary I and, through the sovereign, with the figures of the Immaculate Conception and the Sacred Heart.

\section{Subjectivities and symbolisms}

It is very unusual to paint so many portraits in an altarpiece. This can be explained from the desire of the Queen to see represented the benefits of her political action inspired on the Sacred Heart cult. In the future, the research could give back the name of the black woman, as well as of some of the other people represented in the left's group. But the presence of the black woman within the Real Casa Pia is also uncommon.

Indeed, in 1794, in the Saint Margaret of Cortona section, there were 215 women; 42 of whom went from there to the section of Our Lady of Immaculate Conception. The archival documentation does not provide information on the number of black women belonging to the section of the Immaculate Conception. However, there are data on the total number of black women who entered the Casa Pia from 1780 to 1799. They were a very low number, and this fact could be testimony that Casa Pia's assistance was aimed mainly of white women. From 1780 to 1789 were reclused in the Real Casa Pia only six black women: two from Lisbon, and four from Angola. From 1789 to 1799, among 1002 women registered, only thirty-two were described as "pretas" or "pardas". Five of them declared to "ser escrava", and two freedwomen. ${ }^{1}$ The black woman portraited by Giuseppe Trono was included among these thirty-two, and her exemplary religious life justified her presence in the left group in the altarpiece of the Bemposta chapel.

Even if studies on the subject still lack, it is possible to argue that the welfare strategies of politics of Mary l's government were not primarily aimed at the ex-enslaved people. Considering that the laws of the marquis of Pombal had abolished slavery in the territory of the Portuguese kingdom in 1761 and 1769, the living conditions of black women and men in Lisbon in the second half of the $18^{\text {th }}$ century need to be better known (Castro Henriques, 2008; Caldeira, 2017). Travelers generally agree in describing the city as extremely miserable, full of indigents, dirty, and dangerous.

The painting of Bemposta chapel is not only the most interesting collective portrait, after the great famous Portuguese artwork of Paineis de São Vicente. It represents, also, multiple levels of meaning that go beyond the personal biographies of all those who have been represented, nobles and ordinary people.

\footnotetext{
${ }^{1}$ Lisbon, Arquivo da Casa Pia, Casa de Correção para mulheres. Assentos, 1780-1789, I, cod. 3810; Casa de Correção para mulheres. Assentos, 1789-1799, II, cod. 3811.
} 
The symbol of the wind rose painted on the floor, on which the royal family is placed, visualizes the maritime and colonial power of the Portuguese monarchy, and it connects the painting to the wider meaning of the canvas by Pompeo Batoni in the Basilica of Estrela. The two artworks are closely linked and their iconographies reveal the importance of the government of Angola in the second half of $18^{\text {th }}$ century (Santos, 2005). Indeed, Maria I continued the politics on the African colony started in the previous reign under the command of the Marquis of Pombal. The painting of Pompeo Batoni visualizes the three dominated continents, giving to Africa a central position within the global composition. The same is visible in the Trono's painting, where the position of the three women in front of Queen Mary reproduces the same distribution of the four continents seen in the Basilica of Estrela. So, at this level of symbolic interpretation, the black woman, as well the other two, acquire an allegorical meaning. The canvas of the Basilica displays the concept of worldwide diffusion of the Sacred Heart cult to consolidate the alliance between monarchy and church. The Bemposta's canvas shows the concretization of policies to be implemented in the Portuguese overseas colonial territories, not only in the city of Lisbon. Indeed, the coercive and educational action implemented in the Real Casa Pia aimed to correct the reclused people and to teach them "obedience to Roman Catholicism, to laws and those due to kings" (Beirão, 1944: 247). The education to obey and the alliance between monarchy and church were the milestones to consolidate the power against the revolutionary threats.

\section{Changing the approach}

Giving back visibility, subjectivity and narrative to the black people painted in the earlymodern Portuguese artworks allows to rethink the colonial past and the nowadays Portuguese society (Bindman, Gates \& Dalton, 2011). It is meaningful that in the in-depth study on the painting The earthquake of 1755, carried out in 2018, has not been underlined the presence of black people (Markl \& Bastos, 2018). The large canvas, produced in the second half of the $18^{\text {th }}$ century, represents the destruction of Lisbon, but it is not a 'photographic' document. The painter, João Glama, staged a representation of the earthquake, including in it the academic repertory of artistic models. 


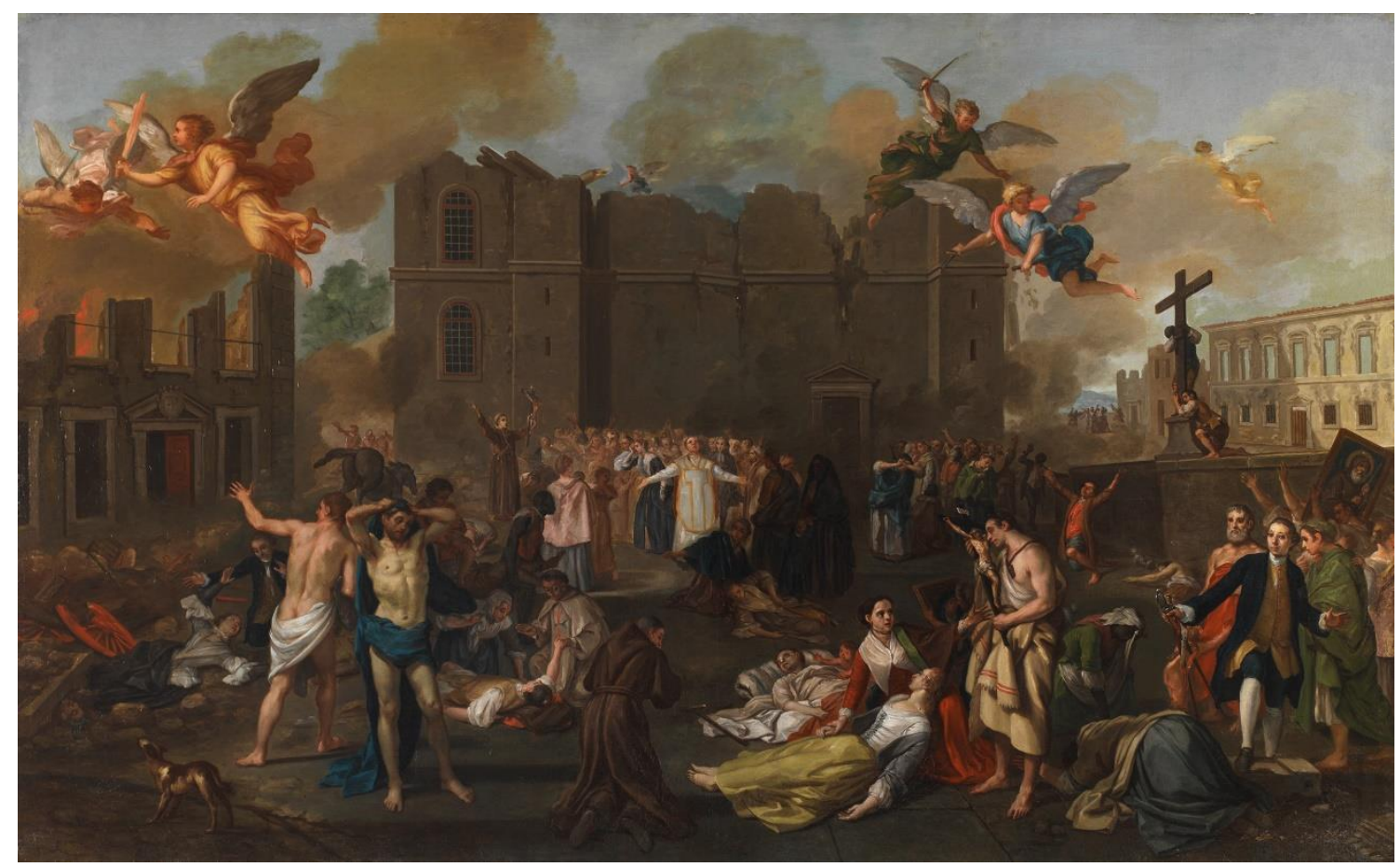

Figure 9: João Glama, The earthquake of 1755.

The analysis of the painting's composition reveals that each group of people includes blacks. On the upper right corner, the black man who hugs the cross; on the lower right side, the black woman who cries; on the left, behind the academic studies of the naked bodies, the black man who helps to carry a wounded person; on the center, the woman who soothes a little girl. Their presence is not accidental but, until now, it was not detected.
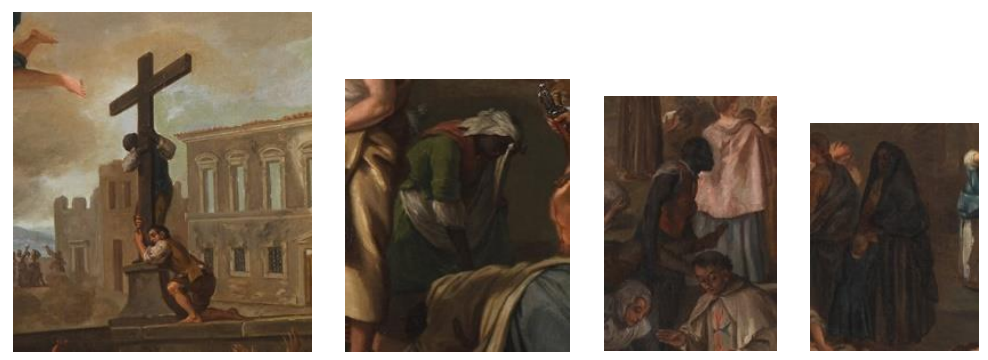

Figure 10: Black people painted in The earthquake of 1755 by João Glama $\left(2^{\text {nd }}\right.$ half of $18^{\text {th }}$ century). Details.

The study of the social, political, racial, and artistic implications for better understanding this painting is opening new horizons of knowledge; for example, to give a deep insight into the dynamics of Portuguese society after the Marquis of Pombal laws; or to rethink the role of black figures within the production of academic paintings by Portuguese artists, who based on the models of the early-modern European masterpieces; or to 
consider the relation with Enlightenment scientific thinking and the $19^{\text {th }}$ century processes of racialization (Rattansi, 2007).

The plural approach of analysis allows to understand the art painting from multiple perspectives. Mascarada Nupcial is another meaningful study-case. Exist two versions of the same painting, and the comparation clearly demonstrates the ambiguity between scientific and artistic value to represent black people in the $18^{\text {th }}$ century Portuguese arts. On one hand, the princess of Brazil Francisca Benedicta of Braganza, who shared with her husband-nephew, the prince Joseph, the interest on scientific knowledge, commissioned a painting in which the black and indigenous dwarfs had to be represented and described exactly as they physically were (height, proportions, skin characteristics and so on).

On the other hand, the version commissioned by Queen Mary I aims more to stage a theatrical scene. The iconography is the same, but the bodies proportion reveals little but significant differences. The taste for the theatrical representation prevails. Indeed, Mary I and her husband-uncle Peter III loved opera music and the court's life was characterized by musical representations of operas and comedies (Raggi, 2018; Braga, 2009). In this painting, the dwarfs 'stage' a theatrical marriage, probably as usually occurred at the royal court to delight the royal couple, representing a 'funny' mirror of the court. At the top of the pyramidal composition, there is the enslaved Martinho de Melo e Castro, from Pernambuco. The married couple is constituted by Rosa, who was baptized in Lisbon with the name Rosa of the Sacred Heart of Jesus, and Pedro, who was older than Rosa. Both were from Angola. The other dwarfs are Marcelino of Tapuia, from Pará (Brazil); Anna from Mozambique; José, from Rio de Janeiro; Ciriaco, from Bahia, who was not a dwarf but was piebald; and Sebastião, from Mozambique.

The homonymy between the dwarf Martinho de Melo e Castro and the name of the minister of the overseas affairs, who is recognizable behind prince John in the painting of Giuseppe Trono, adds a political meaning to the painting. The different origins of the other portraited dwarfs are from all overseas Portuguese colonies: Brazil, Pará, Mozambique, and, once again in prominent position, Angola. The name of "Rosa of the Sacred Heart of Jesus" establishes a link with the politics implemented by Queen Mary $I$ in Portugal and in overseas empire. Thus, the political and religious meaning of the altarpieces in the Bemposta chapel and in the Basilica of Estrela is 're-staged' here in another way.

The current study of the personal lives, at the royal palace of Belém, of the black and indigenous portrayed dwarfs is enriching the knowledge on the plural meaning of the early-modern art in Portugal. This on-going research and the change of approach will 
allow to re-discovery agency and subjectivity of Blacks within Portuguese and European art and society.

\section{Acknowledgment}

This publication results from the support of the Portuguese Science and Technology Foundation, under the program Individual Scientific Employment (CEECIND / 04792/2017 / CP1402 / CT0009), on the topic: Early-modern art and architecture, Atlantic slave trade and cross-cultural dynamics. The case of African Portugal between heritage and politics of recognition. It is, also, part of the project ECHOES European Colonial Heritage Modalities in Entangled Cities that has received funding from the European Union's Horizon 2020 research and innovation programme under grant agreement № 770248.

\section{Referências bibliográficas}

Academia Militar. (Eds.). (2005). D. Catarina de Bragança e o Paço da Rainha. Lisbon: Europress.

Beirão, C. (1944). D. Maria I, 1777-1792. Lisbon: Emprensa Nacional de Publicidade.

Bethencourt, F. (2015/2013). Racismos: das cruzadas ao século XX. Lisbon: Temas \& Debates.

Bindman, D.; Gates, H. L. Jr.; Dalton K. C.C. (Eds). (2011). The image of the Black in Western Art. The Eighteenth century. Part III. Harvard: University Press.

Boyd, A. (2009). Diário de William Beckford em Portugal e Espanha. Lisbon: Biblioteca Nacional.

Borges, N. C. (1986). História da Arte em Portugal - Do Barroco ao Rococó. Vol. 9. Lisbon: Publicações Alfa.

Braga, I. M. R. M. D. (2009). Os «Pretos da Rainha». Serviçais exóticos na Corte de D. Maria I. In Atas do IV Congresso Histórico de Guimarães, Do Absolutismo ao Liberalismo, vol.2 (pp.36-67). Guimarães: Câmara Municipal de Guimarães.

Caldeira, A. (2017). Escravos em Portugal. Das origens ao século XIX. Lisbon: A Esfera dos Livros.

Canosa, R. \& Colonnello, I. (2004). Storia della prostituzione in Italia. Dal Quattrocento alla fine del Settecento. Rome: Edizioni Multimediali.

Castro Henriques, I. (2008). A herança africana em Portugal. Lisbon: CTT.

Degortes, M. (2016). Ensino artístico no estrangeiro e relações internacionais: o caso da Academia Portuguesa de Belas Artes em Roma. In M. J. Neto \& M. Malta (Eds.), 
Coleções de arte em Portugal e Brasil nos séculos XIX e XX (pp. 137-148). Casal de Cambra: Caleidoscópio.

Franco, A., Oliveira, F. \& Vale, P. Pires de. (Eds.). (2018). Do tirar polo natural. Inquérito ao retrato português. Lisbon: Imprensa Nacional Casa da Moeda.

França, J.A. (1967). A arte em Portugal no século XIX. Vol..I. Lisbon: Editorial Estampa.

Alienor, Conseil des Musées (2013). Un regard, une oeuvre, La mascarade nuptiale. José C. Roza, 1788. Retrieved from https://www.alienor.org/publications/mascaradenuptiale/

Markl, A. \& Bastos, C. (2018). Anatomia de uma pintura. João Glama e O terramoto de 1755. Lisbon: MNAA.

Menozzi, D. (2001). Sacro Cuore. Un culto tra devozione interiore e restaurazione cristiana della società. Rome: Viella.

Moita, L. (2005/1955). A Bemposta. O “Paço da Rainha”. Lisbon: Livros Horizontes.

Raggi, G. \& Degortes, M. (2018). A pintura de Giuseppe Trono na Capela do Paço da Bemposta - Academia Militar. Lisbon: Edições Colibri

Raggi, G. (2018). Trasformare la cultura di corte: la regina Maria Anna d'Asburgo e l'introduzione dell'opera italiana in Portogallo. Revista Portuguesa de Musicologia, 5/1, 18-30.

Rattansi, A. (2007). Racism. A very short introduction. Oxford: Oxford University Press.

Rossa, W. \& Ribeiro, M. Calafate. (2015). Patrimónios de influência portuguesa. Coimbra: Imprensa da Universidade de Coimbra.

Santos, C. M. (2005). Um governo "polido" para Angola. Reconfigurar dispositivos de domínio (1750 - c. 1800). PHD Thesis, Universidade Nova de Lisboa, Lisbon, Portugal. Retrieved from: http://catalogo.bn.pt

Silva, C. (1896). Real Casa Pia de Lisboa. Breve história. Lisbon: Tipografia Brito Nogueira.

Stilwell, I. (2018). D. Maria I. Uma rainha atormentada por um segredo que a levou à loucura. Lisbon: Manuscrito.

Tavares, A. \& Pinto, J. dos Santos. (1990). Pina Manique um homem entre duas épocas. Lisbon: Casa Pia. 
Giuseppina Raggi is Art Historian (PhD, 2005), and Researcher at the Centre for Social Studies (University of Coimbra). She is expert on quadratura painting and she currently focuses her investigations on the female patronage in 18th century arts and architecture, and on the agency of enslaved, freed and free Africans and Afrodescendants in early-modern Portugal. She is coleading the project 1719-2019. Filippo Juvarra, Domenico Scarlatti e o papel das mulheres na promoção da ópera e do teatro em Portugal, funded by Calouste Gulbenkian Foundation and she is research member of the European Project ECHOES. European Colonial Heritage Modalities in Entangled Cities.

\giuseppinaraggi@ces.uc.pt 